\title{
Adsorption and desorption of arsenic and its immobilization in soils
}

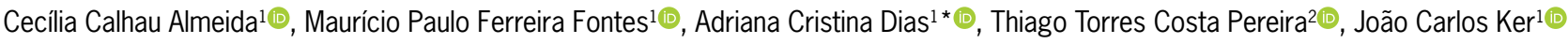

\author{
¿Universidade Federal de Viçosa/CCA - Depto. de Solos, Av. \\ Peter Henry Rolfs, s/n - 36570-900 - Viçosa, MG - Brasil. \\ 2Universidade do Estado de Minas Gerais - Depto. de \\ Ciências Exatas e da Terra, Av. Professor Mário Palmerio, \\ 1001 - 38200-000 - Frutal, MG - Brasil. \\ *Corresponding author <dias.adrianacristina@yahoo.com.br>
}

Edited by: Tiago Osório Ferreira

Received November 14, 2018

Accepted February 28, 2020
ABSTRACT: Arsenic (As) is a naturally occurring chemical element considered toxic and carcinogenic by health and environmental protection agencies. Studies of As adsorption/ desorption behavior in soils are important to predictions of As' potential mobility in natural systems. The aim of this study was to assess the adsorption of As(V) in soils from Minas Gerais, Brazil, and determine its immobilization rate in order to identify soils with characteristics more favorable to its deployment as an As geochemical barrier. The adsorption experiment was performed using different As concentrations and the data pertaining to the maximum adsorption capacity of As(V) (MACAs) were determined by Langmuir and Freundlich isoterms. The Oxisols, due to their more oxidic mineralogy, especially more gibbsitic, and clayey texture, showed the highest MACAs, followed by Ultisols, Inceptisols, and Entisols. In terms of the desorption of As the Inceptisols were the soils that showed the most As desorption. Both As desorption and mobility was lower in the more oxidic and clayey soils. In all soils, the total amount of As was desorbed in due course, but the As release ratio tended to decrease with the passage of time. In general, soils with higher MACAs did not necessarily show less As desorption. For use as a geochemical barrier, as important as a high adsorption capacity of As by the soil is a low As desorption rate. The increase in As mobility may increase the risks of contaminating the supplies of water. To be a good As geochemical barrier the soil has to be a clayey Oxisol, with relatively high amounts of $\mathrm{Fe}$ and $\mathrm{Al}$ oxides, especially gibbsite.

Keywords: toxic contaminant, maximum adsorption capacity, mineralogy of soils, texture, geochemical barrier

\section{Introduction}

Arsenic (As) is a toxic and carcinogenic element according to senior health and protection and health agencies (WHO, 2001; USEPA, 2007). In order to minimize the harmful effects of this chemical element on health, the value of $0.01 \mathrm{mg} \mathrm{L}^{-1}$ of As was selected as the standard of the maximum permissible level by the World Health Organization (WHO, 1993) for drinking water quality.

Adsorption/desorption of As is the main factor that impacts As mobility in soils (Zhang and Selim, 2005). These adsorption and desorption balances are controlled by the mineral and organic matrices of soils (Dias et al., 2019). Many studies have sought to clarify the role of minerals, soils, and sediments in the retention and release of As into the environment (Ladeira and Ciminelli, 2004; Zhang and Selim, 2005; Mello et al., 2006; Borba et al., 2017; Dias et al., 2019; Fontes et al., 2019). Knowing the types of interaction involved makes it possible to predict the destination of As in relation to potential environmental changes (Zhang and Selim, 2005).

Oxidic surfaces, especially $\mathrm{Fe}$ and $\mathrm{Al}$ oxyhydroxides, have a high affinity for As (Cui and Weng, 2013), and they are important components of the clay fraction of soils in Minas Gerais (Fontes and Weed, 1991) where the mining process has caused problems with As contamination, e. g. in the municipalities of Ouro Preto, Mariana and Paracatu. In these counties As contents in the sediments and water are very high, and can reach as much as $4500 \mathrm{mg} \mathrm{kg}^{-1}$ in sediments and $350 \mathrm{\mu g} \mathrm{L}^{-1}$ in water (Pimentel et al., 2003; Mello et al., 2006; Varejão et al., 2011; Borba et al., 2017; Fontes et al., 2019).

For the geochemical purpose of immobilizing As, soils with high adsorption capacity and low desorption capacity of As are excellent for remediation procedures since they are able to form a natural seepage barrier to surrounding soils, groundwater and the environment (Ladeira and Ciminelli, 2004). Soils with predominantly oxidic mineralogy and clayey texture, such as Oxisols and certain Ultisols, are more favorable to retaining As in their application as a geochemical barrier to immobilize this element. Thus, the aim of this study was to determine the adsorption of $\mathrm{As}(\mathrm{V})$ in the $\mathrm{A}$ and B horizons of representative soils from Minas Gerais, and determine its mobilization rate by means of the desorption of $\mathrm{As}(\mathrm{V})$, in order to identify the most suitable soil class and attributes to be used as a geochemical barrier for As.

\section{Materials and Methods}

\section{Soil sampling}

Twenty-three representative profiles of the main soil classes of the state of Minas Gerais, Brazil (Figure 1), were collected at depths of 0 to $20 \mathrm{~cm}$ (A horizon) and 50 to $70 \mathrm{~cm}$ (B horizon) (Table 1). The soil samples were dried and sieved in order to obtain the air-dried fine earth (ADFE). The taxonomic classification of soils was based on the U. S. Soil Taxonomy (Soil Survey Staff, 2014) according to categorization system of the Brazilian System of Soil Classification (EMBRAPA, 2013). 


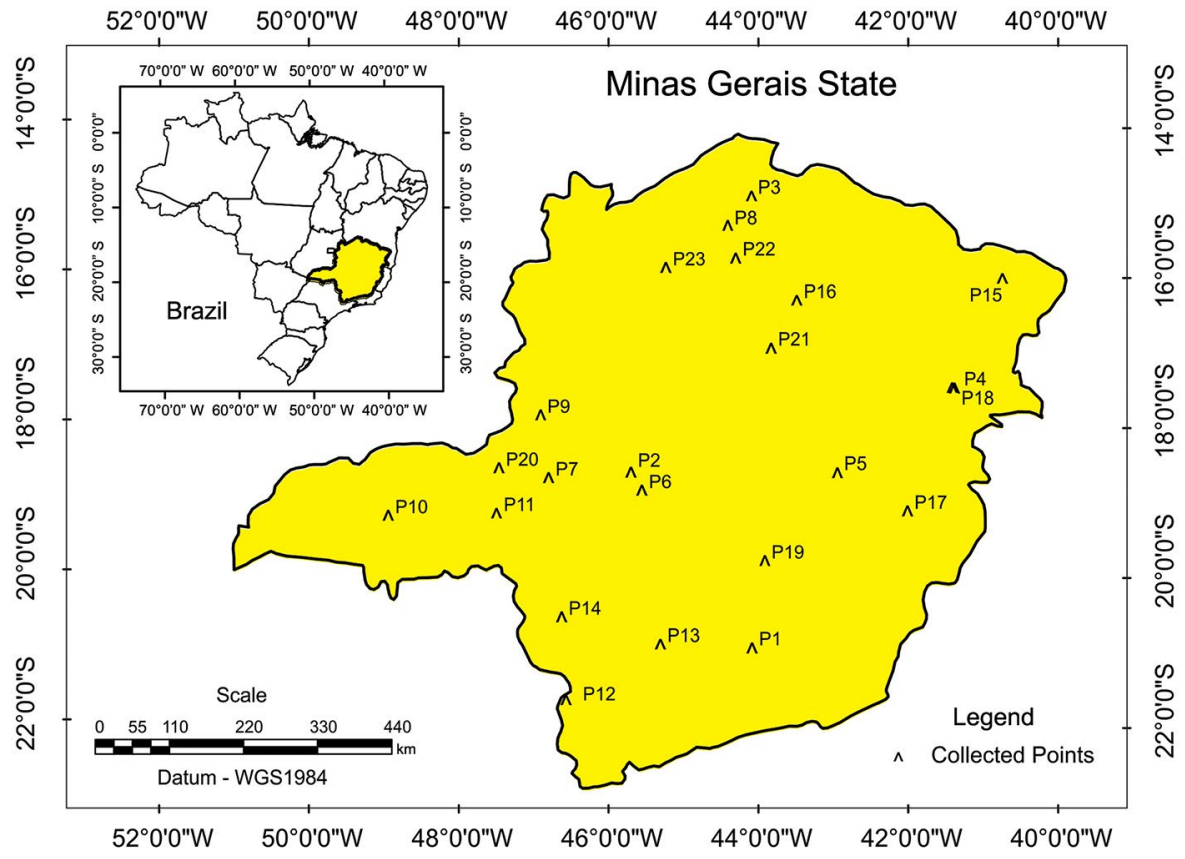

Figure $\mathbf{1}$ - Location of the collected soils in the state of Minas Gerais, Brazil.

\section{Physical, chemical and eletrochemical analysis of soils \\ The clay content was determined by the pipette} method after removal of organic matter and iron oxides (EMBRAPA, 2011). For separate particle size fractions, ADFE samples were subjected to slow shaking (16 h) in a vertical shaker with $\mathrm{NaOH} 0.1 \mathrm{~mol} \mathrm{~L}^{-1}$. The sand fraction was retained on a $53 \mu \mathrm{m}$ sieve and then the clay and silt fractions were separated by sedimentation (Jackson, 1979).

The $\mathrm{pH}$ was potentiometrically measured using a combination glass electrode, calibrated with a buffer solution in $\mathrm{pH} 7.01$ and 4.00 at room temperature, immersed in soil:liquid suspension in a ratio of $1: 2.5$ (EMBRAPA, 2011). Exchangeable Al was determined by titration, after extraction with $\mathrm{KCl} 1 \mathrm{~mol} \mathrm{~L}^{-1}$ in a ratio of 1:10 (EMBRAPA, 2011). Total organic carbon was determined by titration of the remaining potassium dichromate with ammoniacal ferrous sulfate after the wet oxidation process (Yeomans and Bremner, 1988).

Iron and Aluminum forms were determined by the dithionite-citrate methods (Coffin, 1963) and $0.2 \mathrm{~mol} \mathrm{~L}^{-1}$ ammonium acid oxalate at pH 3.0 (McKeague and Day, 1966). Quantification of the elements was carried out using an atomic absorption spectrophotometer (Varian SpectrAA 220A).

The point of zero salt effect (PZSE) was determined for all soil samples through potentiometric titration (Fontes et al., 2001), using modified traditional methods (Parks and Bruyn, 1962; Van Raij and Peech, 1972). A mass of $2 \mathrm{~g}$ of each sample was added to $12.5 \mathrm{~mL}$ of
$\mathrm{NaCl}$ solution $\left(0.001,0.01\right.$, and $\left.0.1 \mathrm{~mol} \mathrm{~L}^{-1}\right)$, in $50 \mathrm{~mL}$ polypropilene tubes for a period of $24 \mathrm{~h}$. After the contact time the samples were acidified with $\mathrm{HCl}$ to a $\mathrm{pH}$ of $\sim 3.0$, and titrated with $\mathrm{NaOH}$. The titration curves were derived by a graphic program where the equivalence point was determined with $\mathrm{HCl}$. The overlap of the four curves permitted the obtaining of a crossing point where $\mathrm{pH}=$ PZSE.

\section{Mineralogical soils analysis}

Minerals from sand, silt and clay fractions were identified by X-ray diffraction (XRD) analyses using an X'PERT PRO PANALYTICAL diffractometer (CoK $\alpha$ radiation) in the range of 4 to $45^{\circ} 2 \theta$ with intervals of $0.02{ }^{\circ} 2 \theta$ to 1 step s${ }^{-1}$, voltage of $40 \mathrm{kV}$, and current of $30 \mathrm{~mA}$.

Thermogravimetric analyses were performed on Shimadzu TGA 50 equipment. The samples were packed in alumina cell. The thermobalance worked with constant flux of nitrogen atmosphere and the temperature range of the analysis was between ambient temperature and $800{ }^{\circ} \mathrm{C}$, at a heating rate of $10^{\circ} \mathrm{C}$ per $\min$.

\section{Arsenic (V) adsorption}

The experiment of As (V) adsorption was conducted in triplicate on the surface and subsurface horizons in twenty-three representative profiles of the main soil classes of the state of Minas Gerais (Table 1). Solutions of $0.001 \mathrm{~mol} \mathrm{~L}^{-1} \mathrm{NaNO}_{3}$ containing $\mathrm{Na}_{2} \mathrm{HAsO}_{4} \cdot 7 \mathrm{H}_{2} \mathrm{O}$ were used at doses of $0.0,6.0,12.0,18.0,30.0,42.0$, $54.0,66.0,84.0,102.0$, and $120.0 \mathrm{mg} \mathrm{L}^{-1}$ of $\mathrm{As}(\mathrm{V})$ with a 
Table 1 - Soil classification and location of the studied soils, in the state of Minas Gerais.

\begin{tabular}{|c|c|c|c|c|}
\hline \multirow{2}{*}{$\begin{array}{l}\text { Soil } \\
\text { Identification }\end{array}$} & \multirow{2}{*}{$\begin{array}{l}\text { USDA Soil } \\
\text { Taxonomy }\end{array}$} & \multicolumn{3}{|c|}{ Geographic coordinates } \\
\hline & & $\begin{array}{c}\text { Elevation } \\
\text { (m) }\end{array}$ & Latitude & Longitude \\
\hline \multicolumn{5}{|c|}{ Oxisol } \\
\hline P1 & Acrudox & 979 & $-44^{\circ} 05^{\prime} 06.79^{\prime \prime}$ & $-21^{\circ} 06^{\prime} 31.32^{\prime \prime}$ \\
\hline P2 & Acrudox & 1032 & $-45^{\circ} 42^{\prime} 01.39^{\prime \prime}$ & $-18^{\circ} 46^{\prime} 05.26^{\prime \prime}$ \\
\hline P3 & Eutrustox & 445 & $-44^{\circ} 05^{\prime} 47.95^{\prime \prime}$ & $-15^{\circ} 05^{\prime} 09.75^{\prime \prime}$ \\
\hline P4 & Hapludox & 306 & $-41^{\circ} 24^{\prime} 53.64^{\prime \prime}$ & $-17^{\circ} 38^{\prime} 25.04^{\prime \prime}$ \\
\hline P5 & Hapludox & 778 & $-42^{\circ} 56^{\prime} 48.60^{\prime \prime}$ & $-18^{\circ} 46^{\prime} 22.19^{\prime \prime}$ \\
\hline P6 & Acrudox & 886 & $-45^{\circ} 33^{\prime} 14.00^{\prime \prime}$ & $-19^{\circ} 00^{\prime} 25.70^{\prime \prime}$ \\
\hline P7 & Hapludox & 915 & $-46^{\circ} 47^{\prime} 56.67^{\prime \prime}$ & $-18^{\circ} 50^{\prime} 21.82^{\prime \prime}$ \\
\hline P8 & Eutrustox & 434 & $-44^{\circ} 24^{\prime} 37.12^{\prime \prime}$ & $-15^{\circ} 28^{\prime} 35.71^{\prime \prime}$ \\
\hline P9 & Hapludox & 654 & $-46^{\circ} 54^{\prime} 26.77^{\prime \prime}$ & $-18^{\circ} 00^{\prime} 02.09^{\prime \prime}$ \\
\hline $\mathrm{P} 10$ & Hapludox & 631 & $-48^{\circ} 56^{\prime} 21.79^{\prime \prime}$ & $-19^{\circ} 20^{\prime} 35.69^{\prime \prime}$ \\
\hline P11 & Hapludox & 910 & $-47^{\circ} 29^{\prime} 50.89^{\prime \prime}$ & $-19^{\circ} 18^{\prime} 59.71^{\prime \prime}$ \\
\hline P12 & Hapludox & 1530 & $-46^{\circ} 34^{\prime} 04.46^{\prime \prime}$ & $-21^{\circ} 48^{\prime} 21.87^{\prime \prime}$ \\
\hline \multicolumn{5}{|c|}{ Ultisol } \\
\hline P13 & Paleudults & 864 & $-45^{\circ} 18^{\prime} 26.32^{\prime \prime}$ & $-21^{\circ} 03^{\prime} 57.78^{\prime \prime}$ \\
\hline P14 & Paleudults & 745 & $-46^{\circ} 37^{\prime} 44.03^{\prime \prime}$ & $-20^{\circ} 41^{\prime} 43.90^{\prime \prime}$ \\
\hline P15 & Paleustults & 205 & $-40^{\circ} 44^{\prime} 35.59^{\prime \prime}$ & $-16^{\circ} 11^{\prime} 07.84^{\prime \prime}$ \\
\hline P16 & Paleustults & 650 & $-43^{\circ} 29^{\prime} 27.97^{\prime \prime}$ & $-16^{\circ} 28^{\prime} 43.32^{\prime \prime}$ \\
\hline P17 & Hapludults & 318 & $-42^{\circ} 00^{\prime} 38.96^{\prime \prime}$ & $-19^{\circ} 17^{\prime} 06.47^{\prime \prime}$ \\
\hline P18 & Paleustults & 347 & $-41^{\circ} 23^{\prime} 01.28^{\prime \prime}$ & $-17^{\circ} 38^{\prime} 37.14^{\prime \prime}$ \\
\hline \multicolumn{5}{|c|}{ Inceptisol } \\
\hline P19 & Dystrudepts & 751 & $-43^{\circ} 54^{\prime} 56.72^{\prime \prime}$ & $-19^{\circ} 56^{\prime} 48.98^{\prime \prime}$ \\
\hline P20 & Dystrudepts & 890 & $-47^{\circ} 27^{\prime} 55.86^{\prime \prime}$ & $-18^{\circ} 42^{\prime} 30.34^{\prime \prime}$ \\
\hline P21 & Dystrudepts & 676 & $-43^{\circ} 49^{\prime} 54.86^{\prime \prime}$ & $-17^{\circ} 06^{\prime} 40.38^{\prime \prime}$ \\
\hline P22 & Haplustepts & 602 & $-44^{\circ} 18^{\prime} 16.08^{\prime \prime}$ & $-15^{\circ} 54^{\prime} 33.43^{\prime \prime}$ \\
\hline \multicolumn{5}{|c|}{ Entisol } \\
\hline P23 & Quartzipsamments & 499 & $-45^{\circ} 14^{\prime} 07.14^{\prime \prime}$ & $-16^{\circ} 02^{\prime} 15.98^{\prime \prime}$ \\
\hline
\end{tabular}

USDA = Soil Classification based on the U.S. Soil Taxonomy (Soil Survey Staff, 2014).

$\mathrm{pH}$ adjusted to 5.5. This $\mathrm{pH}$ value was chosen because it was close to the average $\mathrm{pH}$ values recorded in previous studies on the soils in Minas Gerais (Skorupa et al., 2012).

We placed $50 \mathrm{~mL}$ of each solution and $0.5 \mathrm{~g}$ of soil in polypropylene tubes with a capacity of $50 \mathrm{~mL}$. The soils were placed under suspension by vertical stirring at $45 \mathrm{rpm}$ for $24 \mathrm{~h}$. These suspensions were centrifuged and the supernatant filtered for dosing the As using a Perkin Elmer Optima 8300DV Inductively Coupled Plasma Optical Emission Spectrometer (ICP-OES), with a detection limit of $60 \mu \mathrm{g} \mathrm{L}^{-1}$ for As.

\section{Maximum adsorption capacity of $\mathrm{As}(\mathrm{V})$}

The maximum adsorption capacity of As(V) (MACAs) was modeled using the Langmuir isotherm equation $\mathrm{x} / \mathrm{m}=\mathrm{abC} /(1+\mathrm{aC})$. In the equation, $\mathrm{x} / \mathrm{m}$ is the amount of the adsorbed element $\left(\mathrm{mg} \mathrm{g}^{-1}\right), \mathrm{b}$ the maximum adsorption capacity (MAC) of the element by the soil $\left(\mathrm{mg} \mathrm{g}^{-1}\right), \mathrm{C}$ the concentration of the element in the equilibrium solution $\left(\mathrm{mg} \mathrm{L}^{-1}\right)$, and $a$ a constant related to the binding energy of the element to the soil $\left(\mathrm{L} \mathrm{mg}^{-1}\right)$.
The model proposed by Freundlich $\left(\mathrm{x} / \mathrm{m}=\mathrm{kC}^{1 / \mathrm{n}}\right)$ was used for purposes of comparison with the model previously described. In the equation, $x / m$ is the concentration of the element adsorbed on the solid $\left(\mathrm{mg} \mathrm{g}^{-1}\right), \mathrm{C}$ the concentration in the equilibrium solution $\left(\mathrm{mg} \mathrm{L}^{-1}\right)$, and $\mathrm{k}$ and $\mathrm{n}$ are the Freundlich parameters that characterize the adsorption isotherm. The parameter $1 / \mathrm{n}$ is dimensionless, and was linearized with $\log \mathrm{x} / \mathrm{m}$ as a function of $\log C$, building a line with slope $1 / \mathrm{n}$ and intercept $\log \mathrm{k}$, which were used to calculate the $\mathrm{n}$ and $\mathrm{k}$ values. This type of isotherm describes the adsorption of ions in a similar way to that of the Langmuir isotherm, but predicts that the adsorption continues to occur after the complete coverage of the adsorbent surface by a layer of ions, with the adsorption energy decreasing in a logarithmic function as the surface area increases.

\section{Arsenic (V) desorption}

The experiment of As desorption was performed in the subsurface horizons of the collected samples. Doses corresponding to the average of the MACAs were added to $250 \mathrm{~g}$ of each sample and packed in $500 \mathrm{~mL}$ capacity plastic containers. Solutions in a volume corresponding to $60 \%$ of the soil field capacity, previously calculated according to EMBRAPA (2011), were added to the containers. The material was carefully homogenized.

After the contact periods $(1,30$, and 60 days) had elapsed, the soils were oven dried at $40{ }^{\circ} \mathrm{C}$ and slightly ground in a mortar. Subsequently, $0.5 \mathrm{~g}$ of these soils were weighed in polypropylene tubes to which the extractive solutions $\left(\mathrm{Na}_{2} \mathrm{HPO}_{4} \mathrm{H}_{2} \mathrm{O}, \mathrm{Na}_{2} \mathrm{SO}_{4}\right.$, and $\left.\mathrm{NaNO}_{3}\right)$ were added, in accordance with a two-fold molar ratio between the added anions and $\mathrm{As}(\mathrm{V})$ in order to facilitate the desorption. Solutions with a $\mathrm{pH}$ value adjusted to 5.5 were used from the addition of 1 or $2 \mathrm{~mol} \mathrm{~L}^{-1}$ $\mathrm{HCl}$ or $\mathrm{NaOH}$ according to the buffering power of the solution in order to minimize the change in solution volume. The solution was stirred vertically for $24 \mathrm{~h}$ and the supernatant filtered for dosing the As by inductively coupled plasma-optical emission spectrometry (ICPOES). The fraction of As desorbed from the soils was calculated on the bases of the change in concentration in solution (before and after desorption).

\section{Results and Discussion}

\section{Arsenic (V) adsorption}

The data of $\mathrm{As}(\mathrm{V})$ adsorption, adjusted according to the Langmuir and Freundlich equations, are shown in Tables 4 and 5, respectively. The values of the regression coefficient $\left(\mathrm{R}^{2}\right)$ ranged from 0.96 to 0.99 (Equation Langmuir) and from 0.95 to 0.97 (Freundlich equation), indicating that both models efficiently describe the adsorption of As.

The studied soil profiles showed differences in the maximum adsorption capacity of arsenic (MACAs), which is due to the set of chemical, physical, and mineralogical characteristics of the soils (Tables 2 and 
Table 2 - Physical, chemical, electrochemical, and mineralogical characterization of the soils.

\begin{tabular}{|c|c|c|c|c|c|c|c|c|c|c|c|c|}
\hline $\begin{array}{l}\text { Soil } \\
\text { Id. }\end{array}$ & Hor. & Clay (\%) & Textural class & $\mathrm{Al}^{3+}$ & TOC & $\mathrm{Fe}_{\mathrm{D}}$ & $\mathrm{Fe}_{\mathrm{ox}}$ & $\begin{array}{c}\mathrm{Fe}_{\mathrm{ox}} \\
\mathrm{Fe}_{\mathrm{D}}\end{array}$ & $\mathrm{pH}$ & PZSE & $\mathrm{Gb}$ & $\mathrm{Kt}$ \\
\hline$\overline{P 1}$ & $A$ & 64 & Very clayey & 0.51 & 2.73 & 7.43 & 0.10 & 0.01 & 4.94 & 3.64 & 24.4 & 38.6 \\
\hline P1 & Bw & 68 & Very clayey & 0.11 & 0.91 & 4.16 & 0.59 & 0.14 & 4.98 & 4.89 & 22.6 & 48.9 \\
\hline P2 & $A$ & 80 & Very clayey & 0.51 & 2.99 & 6.34 & 0.13 & 0.02 & 4.94 & 3.85 & 41.9 & 24.0 \\
\hline P2 & Bw & 83 & Very clayey & 0.04 & 1.66 & 5.41 & 0.73 & 0.13 & 5.07 & 4.99 & 40.3 & 26.0 \\
\hline P3 & $A$ & 11 & Sandy loam & 0.01 & 1.05 & 3.46 & 0.29 & 0.08 & 6.71 & 4.91 & 5.7 & 62.4 \\
\hline P3 & Bw & 27 & Sandy clay loam & 0.04 & 0.55 & 2.95 & 1.45 & 0.49 & 5.85 & 3.42 & 2.9 & 62.6 \\
\hline P4 & $A$ & 48 & Clay & 0.75 & 1.55 & 1.74 & 0.11 & 0.06 & 5.06 & 3.25 & 2.2 & 85.3 \\
\hline P4 & Bw & 62 & Very clayey & 1.20 & 0.73 & 1.61 & 1.20 & 0.74 & 5.07 & 4.96 & 1.4 & 78.5 \\
\hline P5 & $A$ & 56 & Clay & 0.14 & 2.20 & 5.55 & 1.31 & 0.23 & 5.70 & 4.55 & 6.5 & 70.4 \\
\hline P5 & $\mathrm{Bw}$ & 68 & Very clayey & 0.14 & 0.79 & 5.70 & 1.14 & 0.20 & 4.87 & 4.60 & 6.0 & 68.4 \\
\hline P6 & $A$ & 65 & Very clayey & 2.23 & 8.22 & 2.47 & 0.18 & 0.07 & 4.50 & 3.99 & 15.2 & 40.9 \\
\hline P6 & Bw & 83 & Very clayey & 0.84 & 3.29 & 1.74 & 0.98 & 0.56 & 4.81 & 3.73 & 12.2 & 46.4 \\
\hline P7 & $A$ & 29 & Clay loam & 1.17 & 1.55 & 4.09 & 2.02 & 0.49 & 4.87 & 3.52 & nd & nd \\
\hline P7 & Bw & 40 & Clay & 0.45 & 0.95 & 5.42 & 3.22 & 0.59 & 5.32 & 3.76 & 25.0 & 49.3 \\
\hline P8 & $A$ & 30 & Sandy clay loam & 0.04 & 2.20 & 5.03 & 0.17 & 0.03 & 6.17 & 4.25 & 26.0 & 35.1 \\
\hline P8 & Bw & 42 & Sandy clay & 0.02 & 0.94 & 4.27 & 0.99 & 0.23 & 6.19 & 4.42 & 23.8 & 31.2 \\
\hline P9 & $A$ & 42 & Clay & 0.04 & 2.87 & 7.37 & 0.19 & 0.02 & 6.27 & 5.13 & 6.0 & 70.1 \\
\hline P9 & $\mathrm{Bw}$ & 52 & Clay & 0.14 & 0.69 & 6.31 & 1.25 & 0.19 & 5.26 & 4.56 & nd & 66.7 \\
\hline P10 & $A$ & 14 & Sandy loam & 0.23 & 1.15 & 5.61 & 1.99 & 0.35 & 5.97 & 3.57 & 11.1 & 32.4 \\
\hline P10 & $\mathrm{Bw}$ & 17 & Sandy loam & 1.54 & 0.43 & 10.38 & 2.03 & 0.19 & 4.84 & 5.37 & 15.2 & 26.4 \\
\hline P11 & $A$ & 30 & Sandy clay loam & 1.42 & 4.04 & 9.69 & 0.56 & 0.05 & 4.89 & 3.50 & 10.1 & 39.8 \\
\hline P11 & Bw & 42 & Sandy clay & 0.05 & 0.77 & 10.47 & 0.44 & 0.04 & 5.28 & 3.54 & 9.4 & 36.8 \\
\hline P12 & $A$ & 64 & Very clayey & 2.32 & 1.87 & 6.37 & 1.96 & 0.30 & 4.83 & 4.03 & 32.7 & 29.3 \\
\hline P12 & $\mathrm{Bi}$ & 69 & Very clayey & 2.29 & 0.77 & 8.48 & 1.12 & 0.13 & 5.13 & 4.94 & 32.9 & 24.1 \\
\hline P13 & $A$ & 37 & Clay loam & 0.17 & 3.25 & 4.57 & 0.25 & 0.05 & 5.33 & 3.22 & 6.9 & 62.3 \\
\hline P13 & $\mathrm{Bt}$ & 56 & Clay & 0.35 & 0.80 & 4.22 & 0.95 & 0.22 & 5.15 & 4.43 & nd & nd \\
\hline P14 & $A$ & 22 & Sandy clay loam & 0.05 & 6.4 & 4.83 & 0.47 & 0.09 & 7.19 & 5.98 & 15.6 & 40.8 \\
\hline P14 & Bt & 40 & Sandy clay & 0.11 & 1.2 & 5.41 & 2.34 & 0.43 & 5.66 & 3.37 & 7.9 & 33.8 \\
\hline P15 & $A$ & 23 & Sandy clay loam & 0.04 & 1.2 & 1.86 & 0.14 & 0.07 & 6.56 & 4.66 & 0.7 & 67.7 \\
\hline P15 & $\mathrm{Bt}$ & 33 & Sandy clay loam & 0.03 & 0.7 & 0.75 & 0.19 & 0.25 & 5.96 & 3.34 & 2.1 & 66.0 \\
\hline P16 & $A$ & 34 & Silty clay loam & 0.08 & 2.60 & 4.08 & 0.31 & 0.07 & 6.05 & 3.64 & 6.7 & 44.2 \\
\hline P16 & $\mathrm{Bt}$ & 50 & Silty clay & 1.54 & 0.90 & 3.38 & 2.12 & 0.05 & 4.26 & 5.32 & 3.0 & 32.2 \\
\hline P17 & $A$ & 43 & Clay & 0.05 & 1.50 & 6.05 & 0.26 & 0.04 & 5.61 & 4.34 & 4.2 & 67.7 \\
\hline P17 & $\mathrm{Bt}$ & 66 & Very clayey & 0.05 & 0.50 & 6.01 & 0.85 & 0.14 & 5.47 & 2.86 & 2.0 & 70.4 \\
\hline P18 & $A$ & 25 & Sandy clay loam & 0.51 & 2.90 & 1.52 & 0.21 & 0.13 & 5.19 & 3.16 & 3.0 & 80.8 \\
\hline P18 & $\mathrm{Bt}$ & 44 & Sandy clay & 1.05 & 0.80 & 1.34 & 1.00 & 0.74 & 4.60 & 2.98 & 1.3 & 79.3 \\
\hline P19 & $A$ & 22 & Silt loam & 0.35 & 1.75 & 6.37 & 0.28 & 0.04 & 5.36 & 3.48 & 19.9 & 68.6 \\
\hline P19 & $\mathrm{Bi}$ & 37 & Silty clay loam & 2.57 & 0.91 & 4.66 & 4.95 & 1.06 & 4.95 & 2.98 & 7.0 & 34.6 \\
\hline P20 & $A$ & 17 & Sandy loam & 1.57 & 1.05 & 1.07 & 0.23 & 0.21 & 5.19 & 3.08 & 5.7 & 56.5 \\
\hline P20 & $\mathrm{Bi}$ & 19 & Loam & 4.93 & 0.49 & 0.86 & 1.29 & 1.50 & 5.22 & 2.92 & 4.0 & 59.7 \\
\hline P21 & $A$ & 33 & Silty clay loam & 1.84 & 1.80 & 6.39 & 0.22 & 0.03 & 5.46 & 2.72 & nd & nd \\
\hline P21 & $\mathrm{Bi}$ & 42 & Silty clay & 3.75 & 1.14 & 3.97 & 1.57 & 0.39 & 4.71 & 3.44 & 0.9 & 34.3 \\
\hline P22 & $A$ & 35 & Silty clay loam & 0.08 & 1.83 & 3.38 & 0.23 & 0.06 & 5.73 & 4.58 & 0.7 & 18.3 \\
\hline P22 & $\mathrm{Bi}$ & 39 & Silty clay loam & 0.02 & 2.25 & 3.20 & 1.70 & 0.53 & 6.12 & 4.44 & 2.0 & 17.4 \\
\hline P23 & $A$ & 07 & Loamy sand & 0.75 & 0.71 & 0.36 & 0.16 & 0.44 & 4.96 & nd & 1.6 & 80.6 \\
\hline
\end{tabular}

Soil Id. = Soil Identification; $\mathrm{Al}^{3+}\left(\mathrm{cmol}_{\mathrm{c}} \mathrm{dm}^{-3}\right) ; \mathrm{TOC}=$ total organic carbon (dag $\left.\mathrm{kg}^{-1}\right) ; \mathrm{Fe}_{\mathrm{D}}=\mathrm{Fe}$ extracted by dithionite-citrate; $\mathrm{Fe}_{\mathrm{ox}}=\mathrm{Fe}$ extracted by ammonium oxalate; PZSE = Point Zero Saline Effect; $n d \stackrel{c}{=}$ not determined; $\mathrm{Gb}=$ gibbsite; $\mathrm{Kt}=$ kaolinite.

3). The values of MACAs between the different soil classes presented the following order: Oxisols (P1 to P12) > Ultisols (P13 to P18) > Inceptisols (P19 to P22) $>$ Entisol (P23). The Oxisols, Ultisols, and Inceptisols presented higher MACAs averages in the B horizon when compared to the A horizon. For the same soil class, these differences may be attributed mainly to the texture and oxide content, which are the main factors that determined the variation in the capacity of the soil to act as an adsorbent surface of As. Oxidic soils have predominantly dependent charge surfaces that can attract ionic species such as As (Zhang et al., 2011). 
Table 3 - Mineralogical characterization of the soils.

\begin{tabular}{|c|c|c|c|}
\hline Soil Identification & Sand & Silt & Clay \\
\hline P1 & $\mathrm{Kt}, \mathrm{Gb}, \mathrm{Qz}, \mathrm{Mt} / \mathrm{Mh}, \mathrm{Hm}$ & $\mathrm{Kt}, \mathrm{Qz}, \mathrm{Mi}$ & $\mathrm{Kt}, \mathrm{Gb}, \mathrm{Gt}, \mathrm{II}, \mathrm{Hm}$ \\
\hline P2 & $\mathrm{Qz}, \mathrm{Pg}$ & Kt, Gb, Qz, Gt, Mi & II, Kt, Gb, Hm, Gt \\
\hline P3 & $\mathrm{Qz}, \mathrm{Pg}, \mathrm{Hm}$ & $\mathrm{Kt}, \mathrm{Gb}, \mathrm{Qz}, \mathrm{Gt}, \mathrm{Mi}$ & II, Kt, Gt, Qz, Hm \\
\hline P4 & $\mathrm{Qz}, \mathrm{Pg}$ & $\mathrm{Kt}, \mathrm{Gb}, \mathrm{Qz}$ & $\mathrm{Kt}, \mathrm{Gb}, \mathrm{Gt}$ \\
\hline P5 & $\mathrm{Kt}, \mathrm{Gb}, \mathrm{Qz}, \mathrm{Pg}, \mathrm{Hm}$ & Kt, Gb, Gt, Qz & $\mathrm{Kt}, \mathrm{Gb}, \mathrm{Gt}, \mathrm{Hm}$ \\
\hline P6 & Kt, Pg, Gb, Mi, Felds-K, Qz & Mi, Kt, Gb, Qz, Felds-K, Pg & II, Kt, Gb, Gt \\
\hline P7 & $\mathrm{Kt}, \mathrm{Gb}, \mathrm{Qz}, \mathrm{Mt} / \mathrm{Mh}, \mathrm{Hm}$ & $\mathrm{Kt}, \mathrm{Gb}, \mathrm{Gt}, \mathrm{An}, \mathrm{Qz}, \mathrm{Mh}, \mathrm{Hm}$ & $\mathrm{Kt}, \mathrm{Gb}, \mathrm{Gt}, \mathrm{Hm}$, II \\
\hline P8 & $\mathrm{Qz}, \mathrm{Pg}$ & $\mathrm{Mi}, \mathrm{Kt}, \mathrm{Gb}, \mathrm{Qz}$, Felsd-K & HIV, II, Kt, Gb, Gt, Mh, Hm, \\
\hline P9 & Qz, Pg & $\mathrm{Kt}, \mathrm{Qz}, \mathrm{Pg}, \mathrm{Hm}$ & II, Kt, Gt, Hm \\
\hline P10 & $\mathrm{Qz}, \mathrm{Pg}, \mathrm{Hm}$ & Qz & HIV, II, Kt, Gb, Gt, Hm \\
\hline P11 & $\mathrm{Qz}, \mathrm{Pg}$ & $\mathrm{Qz}, \mathrm{Hm}$ & II, Kt, Gb, Gt, Hm \\
\hline P12 & $\mathrm{Kt}, \mathrm{Gb}, \mathrm{Qz}, \mathrm{Pg}, \mathrm{Hm}$ & $\mathrm{Mh}, \mathrm{Kt}, \mathrm{Gb}, \mathrm{Qz}, \mathrm{An}, \mathrm{Hm}$ & Kt, Gb, Gt, II, Mh, Hm \\
\hline P13 & Qz, Pg, Felds-K & Mi, Kt, Qz, Pg, Felds-K & II, Kt, Gb, Gt, Hm \\
\hline P14 & $\mathrm{Mi}, \mathrm{Qz}, \mathrm{Pg}$ & Kt, Mi, Qz, Pg & II, Kt, Gb, Gt, Hm \\
\hline P15 & $\mathrm{Qz}, \mathrm{Pg}$ & Kt, Qz & II, Kt, Gt, Hm \\
\hline P16 & $\mathrm{Qz}, \mathrm{Pg}$ & Mi, Kt, Qz, Pg, Felds-K & II, Kt, Gt, Hm \\
\hline P17 & $\mathrm{Qz}, \mathrm{Pg}$ & Kt, Mi, Qz, Pg & Kt, Gt, II \\
\hline P18 & Qz, Pg & Kt, Qz & II, Kt, Gt, Hm \\
\hline P19 & Mi, Qz, Gt, Pg & Mi, Kt, Qz, Pg, Felds-K & II, Kt, Gt, Felds-K, Hm \\
\hline P20 & Mi, Qz, Pg, Felds-K & Mi, Kt, Qz, Pg, Felds-K & $\mathrm{Vm} / \mathrm{HIV}, \mathrm{II}, \mathrm{Kt}$ \\
\hline P21 & Qz, Pg, Felds-K, Mi & $\mathrm{Mi}, \mathrm{Kt}, \mathrm{Qz}$ & II, Kt, Gt, Felds-K, Hm \\
\hline P22 & Mi, Qz, Felds-K, Pg & Mi, Qz, Kt & II, Kt, Qz \\
\hline P23 & Qz, pg & $\mathrm{Kt}, \mathrm{Qz}$ & $\mathrm{Kt}, \mathrm{Qz}$ \\
\hline
\end{tabular}

Soil Id. = Soil Identification; Clay = Natural clay; $\mathrm{An}=$ anatase; $\mathrm{Kt}=$ kaolinite; Felds $\mathrm{K}=$ potassium feldspar; $\mathrm{Gb}=$ gibbsite; Gt $=$ Goethite; $\mathrm{Hm}=\mathrm{Hematite} ; \mathrm{II}=$ illite; $\mathrm{Mi}=$ mica; $\mathrm{Mt} / \mathrm{Mg}$ = magnetite/maghemite; $\mathrm{Mh}$ = maghetite; $\mathrm{Qz}=$ quartz; $\mathrm{Pg}$ = plagioclase; $\mathrm{HIV}$ = hydroxy-interlayered vermiculite.

Table 4 - Parameters related to the Langmuir equation for arsenic (V) adsorption in the soils.

\begin{tabular}{|c|c|c|c|c|c|c|c|}
\hline \multirow[t]{2}{*}{$\begin{array}{l}\text { Soil } \\
\text { Identification } \\
\text { (A horizon) }\end{array}$} & b & a & $\mathrm{R}^{2}$ & $\begin{array}{c}\text { Soil } \\
\text { Identification } \\
\text { (B horizon) }\end{array}$ & b & a & $\mathrm{R}^{2}$ \\
\hline & $\mathrm{mg} \mathrm{g}^{-1}$ & $\mathrm{~L} \mathrm{mg}^{-1}$ & & & $\mathrm{mg} \mathrm{g}^{-1}$ & $\mathrm{~L} \mathrm{mg}^{-1}$ & \\
\hline P1 & 2.49 & 1.40 & 0.99 & P1 & 2.55 & 1.53 & 0.99 \\
\hline P2 & 2.45 & 1.04 & 0.99 & P2 & 2.67 & 1.12 & 0.99 \\
\hline P3 & 1.49 & 1.36 & 0.99 & P3 & 1.56 & 1.33 & 0.99 \\
\hline P4 & 2.24 & 1.38 & 0.98 & P4 & 2.85 & 1.16 & 0.99 \\
\hline P5 & 2.64 & 1.18 & 0.99 & P5 & 2.91 & 1.21 & 0.99 \\
\hline P6 & 3.56 & 1.32 & 0.99 & P6 & 3.58 & 1.37 & 0.98 \\
\hline P7 & 2.19 & 1.18 & 0.99 & P7 & 2.46 & 1.26 & 0.97 \\
\hline P8 & 2.35 & 1.14 & 0.99 & P8 & 2.34 & 1.12 & 0.99 \\
\hline P9 & 2.13 & 1.02 & 0.99 & P9 & 2.22 & 1.05 & 0.97 \\
\hline P10 & 1.81 & 0.73 & 0.99 & P10 & 1.78 & 1.33 & 0.99 \\
\hline P11 & 2.20 & 1.20 & 0.99 & P11 & 2.77 & 1.34 & 0.99 \\
\hline P12 & 3.03 & 1.17 & 0.98 & P12 & 3.08 & 1.51 & 0.98 \\
\hline P13 & 1.98 & 1.40 & 0.98 & P13 & 1.93 & 1.34 & 0.99 \\
\hline P14 & 1.46 & 0.91 & 0.99 & P14 & 1.98 & 0.82 & 0.97 \\
\hline P15 & 1.52 & 0.85 & 0.99 & P15 & 1.63 & 0.98 & 0.99 \\
\hline P16 & 1.84 & 1.16 & 0.99 & P16 & 1.88 & 1.12 & 0.98 \\
\hline P17 & 2.62 & 0.91 & 0.99 & P17 & 3.25 & 0.94 & 0.96 \\
\hline P18 & 2.44 & 1.07 & 0.99 & P18 & 2.33 & 1.34 & 0.97 \\
\hline P19 & 1.65 & 1.11 & 0.98 & P19 & 1.81 & 0.73 & 0.98 \\
\hline P20 & 1.51 & 1.09 & 0.99 & P20 & 1.55 & 1.16 & 0.96 \\
\hline P21 & 1.82 & 0.86 & 0.98 & P21 & 1.71 & 0.75 & 0.98 \\
\hline P22 & 1.54 & 0.69 & 0.99 & P22 & 1.67 & 0.85 & 0.99 \\
\hline P23 & 0.99 & 1.01 & 0.96 & & & & \\
\hline
\end{tabular}

Table 5 - Parameters related to the Freundlich equation for arsenic (V) adsorption in the soils.

\begin{tabular}{lccccccc}
\hline $\begin{array}{l}\text { Soil } \\
\text { Identification } \\
\text { (A horizon) }\end{array}$ & $\mathrm{K}$ & $\mathrm{n}$ & $\mathrm{R}^{2}$ & $\begin{array}{c}\text { Soil } \\
\text { Identification } \\
\text { (B horizon) }\end{array}$ & $\mathrm{K}$ & $\mathrm{n}$ & $\mathrm{R}^{2}$ \\
\hline P1 & 1.39 & 0.29 & 0.97 & $\mathrm{P} 1$ & 1.46 & 0.28 & 0.97 \\
P2 & 1.19 & 0.35 & 0.97 & $\mathrm{P} 2$ & 1.34 & 0.34 & 0.97 \\
P3 & 0.84 & 0.28 & 0.98 & $\mathrm{P} 3$ & 0.83 & 0.31 & 0.96 \\
P4 & 1.31 & 0.27 & 0.98 & $\mathrm{P} 4$ & 1.50 & 0.26 & 0.96 \\
P5 & 1.19 & 0.31 & 0.97 & $\mathrm{P} 5$ & 1.46 & 0.28 & 0.95 \\
P6 & 1.30 & 0.37 & 0.97 & $\mathrm{P} 6$ & 1.70 & 0.28 & 0.97 \\
P7 & 1.66 & 0.36 & 0.97 & $\mathrm{P} 7$ & 1.88 & 0.32 & 0.96 \\
P8 & 1.07 & 0.35 & 0.97 & $\mathrm{P} 8$ & 1.25 & 0.30 & 0.96 \\
P9 & 1.17 & 0.32 & 0.97 & $\mathrm{P} 9$ & 1.20 & 0.32 & 0.97 \\
P10 & 1.03 & 0.35 & 0.97 & $\mathrm{P} 10$ & 1.04 & 0.34 & 0.97 \\
P11 & 0.78 & 0.39 & 0.98 & $\mathrm{P} 11$ & 0.97 & 0.30 & 0.96 \\
P12 & 1.10 & 0.34 & 0.97 & $\mathrm{P} 12$ & 1.44 & 0.29 & 0.97 \\
P13 & 0.99 & 0.34 & 0.98 & $\mathrm{P} 13$ & 0.96 & 0.36 & 0.94 \\
P14 & 0.68 & 0.33 & 0.97 & $\mathrm{P} 14$ & 0.88 & 0.33 & 0.97 \\
P15 & 0.65 & 0.38 & 0.97 & $\mathrm{P} 15$ & 0.74 & 0.38 & 0.97 \\
P16 & 0.93 & 0.33 & 0.98 & $\mathrm{P} 16$ & 0.99 & 0.30 & 0.97 \\
P17 & 1.24 & 0.34 & 0.97 & $\mathrm{P} 17$ & 1.53 & 0.34 & 0.96 \\
P18 & 1.23 & 0.33 & 0.98 & $\mathrm{P} 18$ & 1.33 & 0.26 & 0.97 \\
P19 & 0.87 & 0.26 & 0.95 & $\mathrm{P} 19$ & 0.73 & 0.41 & 0.96 \\
P20 & 0.80 & 0.33 & 0.96 & $\mathrm{P} 20$ & 0.83 & 0.30 & 0.97 \\
P21 & 0.85 & 0.33 & 0.98 & $\mathrm{P} 21$ & 0.76 & 0.40 & 0.96 \\
P22 & 0.65 & 0.41 & 0.98 & $\mathrm{P} 22$ & 0.74 & 0.38 & 0.95 \\
P23 & 0.27 & 0.52 & 0.95 & & & & \\
\hline & & & & & & &
\end{tabular}


The highest As adsorption was correlated in studies conducted by Ladeira and Ciminelli (2004), with the highest $\mathrm{Al}$ and $\mathrm{Fe}$ oxy-hydroxide content. Oxides and their precursors have been extensively studied, either singly or in combination with other amendments promoting sorption, due to the fact that it provides greater As immobilization in contaminated soils (Komárek et al., 2013).

High As adsorption capacity in mine Fe-rich soils, showed that the mineralogical soil composition (especially $\mathrm{Fe}$ and $\mathrm{Al}$ oxy-hydroxide content) can be crucial to favoring As immobilization in soils (ArcoLázaro et al., 2016). A similar conclusion was observed in studies conducted on laterite soils (soils with high Fe and $\mathrm{Al}$ oxides-hydroxides) (Maji et al., 2008).

Oxides of $\mathrm{Fe}$ may be used for the attenuation of arsenic in contaminated soils (Hartley and Lepp, 2008). The adsorption behavior of As is dependent on the concentrations of oxides in the soils (Khaska et al., 2018). Studies on sorption of As(V), using hematite and goethite, evaluated as a function of different physico-chemical parameters such as $\mathrm{pH}$ and ionic strength, evidenced the importance of $\mathrm{Fe}$ oxides in As immobilization in soils (Mamindy-Pajany et al., 2009).

Clay content showed a significant positive correlation with the adsorption capacity of $\mathrm{As}(\mathrm{V})$ at a probability of $99 \%$ in both the A and B horizons of the studied soils (Table 6). In addition to the textural class, gibbsite content in the soils was significant at 10 $\%$ in both horizons, showing the role of mineralogy in soil adsorption of As. Soils with clay texture and predominantly oxic mineralogy, such as Oxisols and a number of Ultisols located in the state of Minas Gerais, favor the retention of As and these soil attributes are the factors which determine a geochemical barrier for As (Almeida et al., not published data).

The $\mathrm{As}(\mathrm{V})$ adsorption in the $\mathrm{Al}$ and Fe surface is a product of inner-sphere complexation, preferably via bidentate complexes and a few monodentate complexes (Harrison and Berkheiser, 1982), a fact that portrays the role of $\mathrm{Fe}$ and $\mathrm{Al}$ oxides in the immobilization of arsenic in soils. The authors concluded that As is strongly attracted to sorption sites on solid surfaces, being effectively immobilized by the oxidic minerals present in the soils.

The results showed that the highest values for MACAs $\left(3.56\right.$ and $3.58 \mathrm{mg} \mathrm{g}^{-1}$ respectively in the A and $\mathrm{B}$ horizons) were determined in $\mathrm{P} 6$. This profile, in addition to being classified as a very clayey textured soil, showed a high content of gibbsite, hematite, and goethite (Table 3), with amounts of $25 \%$ of the first mineral (Table 2). Another aspect to be emphasized is the relatively high values of Fe poorly crystallized in these soils, according to the $\mathrm{Fe}_{\mathrm{OX}} / \mathrm{Fe}_{\mathrm{D}}$ ratio (Table 2).

The Oxisol P3 presented the opposite behavior to that observed in P6, exhibiting the lowest MACAs among the Oxisols (Table 4). In spite of having very similar aspects in terms of soil color, the greater differences in this profile can be related to the presence of a 2:1 mineral ratio and less pronounced amounts of gibbsite, which presented contents with a reduction of approximately $69 \%$ (Table 2). The lower effectiveness in As adsorption in samples with a 2:1 clay minerals ratio and low gibbsite content have been reported by Mello et al. (2006). Studies in As adsorption using clay minerals suggested that the $\mathrm{Si}-\mathrm{OH}$ edges are less effective than the Al-OH groups in adsorbing As (Manning and Goldberg, 1997). On the other hand, the presence of

Table 6 - Correlation coefficient between a number of physical, chemical, and mineralogical attributes of the studied soils.

\begin{tabular}{|c|c|c|c|c|c|c|c|c|c|}
\hline Attribute & CEC & TOC & Clay & $\mathrm{Fe}_{\mathrm{D}}$ & $\mathrm{Fe}_{\mathrm{Ox}}$ & $\mathrm{Fe}_{\underline{O X}} / \mathrm{Fe}_{D}$ & $\mathrm{pH}$ & $\mathrm{Gb}$ & $\mathrm{Kt}$ \\
\hline \multicolumn{10}{|c|}{ A horizon } \\
\hline TOC & $0.15^{\circ}$ & 1.00 & & & & & & & \\
\hline Clay & $-0.31^{\circ}$ & $0.46^{* *}$ & 1.00 & & & & & & \\
\hline $\mathrm{Fe}_{\mathrm{D}}$ & $0.13^{\circ}$ & $-0.01^{\circ}$ & $0.02^{\circ}$ & 1.00 & & & & & \\
\hline $\mathrm{Fe}_{\mathrm{ox}}$ & $-0.03^{\circ}$ & $0.38^{\circ}$ & $0.02^{\circ}$ & $0.08^{\circ}$ & 1.00 & & & & \\
\hline $\mathrm{Fe}_{\mathrm{OX}} / \mathrm{Fe}_{\mathrm{D}}$ & $-0.20^{\circ}$ & $0.04^{\circ}$ & $-0.26^{\circ}$ & $-0.55^{\star *}$ & $0.42^{\circ}$ & 1.00 & & & \\
\hline $\mathrm{Gb}$ & $-0.35^{\circ}$ & $0.34^{\circ}$ & $0.46^{* *}$ & $0.38^{\circ}$ & $-0.05^{\circ}$ & $-0.30^{\circ}$ & $-0.17^{\circ}$ & 1.00 & \\
\hline Kt & $-0.01^{\circ}$ & $-0.31^{\circ}$ & $0.07^{\circ}$ & $-0.44^{* *}$ & $-0.28^{\circ}$ & $0.25^{\circ}$ & $0.05^{\circ}$ & $-0.50^{* *}$ & 1.00 \\
\hline \multicolumn{10}{|c|}{ B horizon } \\
\hline TOC & $0.62^{* *}$ & 1.00 & & & & & & & \\
\hline Clay & -0.32 & 0.20 & 1.00 & & & & & & \\
\hline $\mathrm{Fe}_{\mathrm{D}}$ & 0.13 & 0.25 & 0.23 & 1.00 & & & & & \\
\hline $\mathrm{Fe}_{\mathrm{OX}} / \mathrm{Fe}_{\mathrm{D}}$ & 0.12 & -0.01 & -0.28 & -0.33 & 0.62 & 1.00 & & & \\
\hline $\mathrm{pH}$ & $0.63^{* *}$ & 0.26 & -0.39 & 0.12 & 0.12 & -0.09 & 1.00 & & \\
\hline $\mathrm{Gb}$ & -0.14 & 0.40 & $0.46^{* *}$ & $0.49^{* *}$ & 0.21 & -0.13 & -0.38 & 1.00 & \\
\hline $\mathrm{Kt}$ & -0.06 & -0.35 & -0.32 & -0.41 & -0.29 & 0.10 & 0.01 & $-0.60^{* *}$ & 1.00 \\
\hline
\end{tabular}


gibbsite (Al-OH groups) in the soils favors the adsorption of As (Manning and Goldberg, 1997; Ladeira et al., 2001; Mello et al., 2006).

The lower MACAs values found in a number of soils can be explained by the $\mathrm{Fe}_{\mathrm{OX}} / \mathrm{Fe}_{\mathrm{D}}$ ratio. The $\mathrm{P} 3$, for example, has a lower $\mathrm{Fe}_{\mathrm{Ox}} / \mathrm{Fe}_{\mathrm{D}}$ ratio in the $\mathrm{Bw}$ horizon (Table 2). This ratio is an appropriate indicator for the surface activity of the Fe oxides (Schwertmann, 1973). The interaction of As(V) and Fe oxy-hydroxides, including those with reduced crystallinity, is a function predominantly of inner-sphere surface complexes; these complexes contain no water molecules between the adsorbing ion and the surface functional group (Goldberg and Johnston, 2001).

The Oxisols, with their sandy loam texture (P3 and P10) (Table 2) and a predominantly kaolinitic mineralogy (Tables 2 and 3), showed a similar behavior for the As(V) adsorption (Table 4) compared to Inceptisols (P19 to P22).

As regards the Ultisols, the greatest differences between the A and B horizons were observed especially in the Bt horizon of P17, which presented the highest MACAs $\left(3.25 \mathrm{mg} \mathrm{g}^{-1}\right)$, as shown in Table 4 . In this case, an increase in clay content of $23 \%$ was observed in the Bt horizon.

In general, Ultisols showed coarser granulometry and lower oxidic/gibbsitic contents than Oxisols, this possibly being the reason why the average MACAs of the former (2.16 in $\mathrm{Bt})$ is slightly lower than that observed in the latter (2.46 in Bw). Due to the clay translocation, the A horizon of Ultisols often presented a sandy loam or silt loam texture. This situation tends to make soil $\mathrm{pH}$ slightly more alkaline, giving a lower MACAs to the soil with these characteristics compared to more acidic and dystrophic profiles of the Ultisol.

In Inceptisols, the average MACAs were 1.63 $\mathrm{mg} \mathrm{g}^{-1}$ in the A horizon and $1.69 \mathrm{mg} \mathrm{g}^{-1}$ in the $\mathrm{B}$ horizon (Table 4), not substantially different from these values, except for P19. In this soil, the results of As(V) adsorption, considering the high Al content (Table 2), suggested the possibility of the existence of poorly crystallized $\mathrm{Al}$ forms, promoting an increase of $8 \%$ in the MACAs. Increases in $\mathrm{Fe}_{\mathrm{OX}}$ values with depth, together with the higher $\mathrm{Fe}_{\mathrm{OX}} / \mathrm{Fe}_{\mathrm{D}}$ ratio in the $\mathrm{B}$ horizon, may also contribute to the higher adsorption of As in this horizon.

Out of all the Inceptisols, the profile P21 presented the highest MACAs, with a value of 1.82 $\mathrm{mg} \mathrm{g}^{-1}$ of As. This soil, together with P22, presented a silty clay loam texture, with a finer particle size in relation to the others. In addition, the profiles P21 and P22 have the same textural class, but the presence of Fe oxides (Table 3) reveals their importance to studies of As adsorption.

The Entisol presented, as expected, the lowest value of MACAs due to the presence of a mineralogy composed essentially of quartz (Table 3) and kaolinite. Quartz is an inert material and thus the existing adsorption of As can be attributed to the structural Al$\mathrm{OH}$ groups with kaolinite edges.

\section{Arsenic desorption}

Arsenic ion chemical bonding to iron oxides and hydroxides are predominantly a product of innersphere complexes (Fendorf et al., 1997; Ona-Nguema et al., 2005), although an appreciable fraction is retained through physical forces as outer-sphere complexes (Catalano et al., 2008). According to the results shown in Figure 2, the percentage of remobilized or desorbed As differed from one studied profile to another, due to the set of chemical, physical, and mineralogical characteristics of the soils (Tables 1,2, and 3), conferring a specific As retention capacity (Table 4).

Out of the solutions used to desorb the As, sodium phosphate presented a greater power of remobilization of As, followed by the sulfate and nitrate solutions. This is due to the chemical similarity between As and $\mathrm{P}$, forming oxyanions (arsenate and phosphate) in the oxidation state +5 in soils whose environment is predominantly oxidant (Lytle et al., 2005). Even though As adsorption is not reversible, a large amount of sorbed

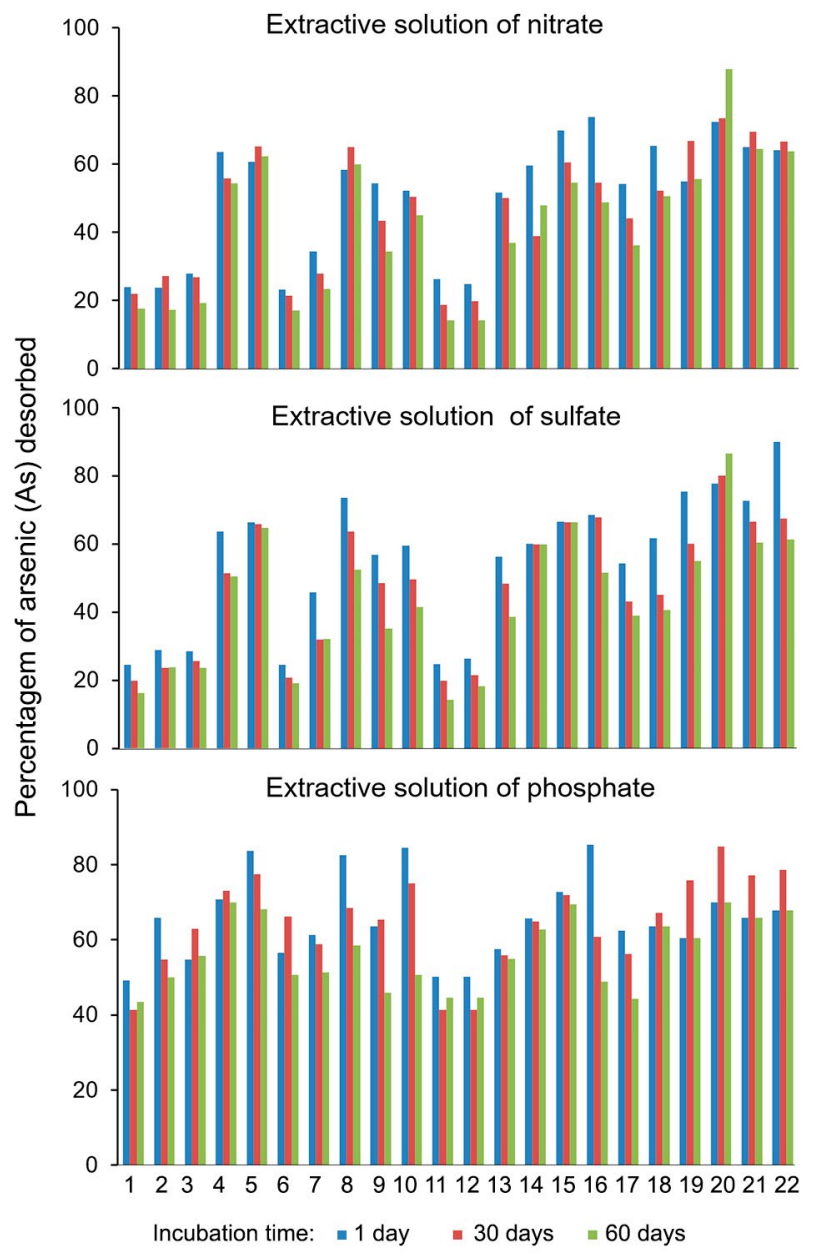

Figure 2 - Percent of arsenic desorbed using extractive solutions of nitrate, sulfate and phosphate as a function of different incubation times. 
As can be released by phosphate which has chemical properties similar to those of $\mathrm{As}(\mathrm{V})$ and can compete favorably with $\mathrm{As}(\mathrm{V})$ for adsorption sites (Zhang et al., 2011). Since phosphate fertilization is very frequent in different agricultural cultivations in tropical soils, attention must be paid to the ability of phosphorus to displace As by occupying the adsorption sites.

The release of As from tailings dams and other mining wastes constitute the major problem with regard to As contamination (Ladeira and Ciminelli, 2004). According to these authors, the mineral arsenopirita (FeAsS), when exposed to weathering, will oxidize, and produce sulfate, soluble As and acidity. Then, the sulfate can compete with As for adsorption sites. A number of authors point out that the mobility of toxic species, such as As, in the environment is a critical point in predicting contamination. For $\mathrm{As}(\mathrm{V}), \mathrm{H}_{2} \mathrm{AsO}_{4}{ }^{-}$predominates $\mathrm{pH}$ values are between 2 and 7 . When the $\mathrm{pH}$ are between 7-11 $\mathrm{HAsO}_{4}{ }^{2-}$ predominates. Both the $\mathrm{H}_{3} \mathrm{AsO}_{4}{ }^{0}$ and $\mathrm{AsO}_{4}{ }^{3-}$ forms may be present under extremely acidic or alkaline conditions, respectively (Smedley and Kinniburgh, 2002). However, the methods applied in adsorption/ desorption studies are not intended to simulate the exact conditions of arsenic release in the environment, but to predict the relative potential hazards of the samples when in contact with certain ions.

Sulfate, nitrate and phosphate are usually present in soils and possibly influence As mobility (Katsoyiannis and Zouboulis, 2002). Except for phosphate, both nitrate and sulfate are anionic species commonly found in sulfidic ore mines (Ladeira and Ciminelli, 2004). Even with soils presenting lower As desorption, when sulfate and nitrate are used, the presence of As is still high in the final solution.

In all soils, As continued to be desorbed over time. However, the percentage of remobilized As tended to decrease in most of them (Figure 2). Previous studies (Lin and Puls, 2000; Mello et al., 2006) have pointed out that the desorption of arsenite and arsenate in clay minerals diminishes the longer the time of residence.

According to the results obtained here, when comparing the percentage of As remobilized in the analysis involving the first ( 1 day), second (30 days), and third incubation time (60 days), As release over time was not reduced at a constant rate (Figure 2). One example is the As release using phosphate as extractor: the P18 (Ultissol), P19-21 (Inceptisols) and P22 (Entisols), are soils with lower clay content (Table 2) and are less oxidic. In these samples, the As remobilized in 60 days are similar to the first incubation period. In less weathered soils, such as Inceptisols and Entisols, there was no marked decrease in the rate of As release over time (after 60 days of incubation, approximately $60 \%$ As was released using the three extractors).

Arsenic release (Figure 2) tended to be lower as the more clayey and oxidic the soils were (Table 3). The more weathered soils, such as Oxisols (P1-12) and Ultisols (P13-17) showed reductions in the percentage of remobilization of As over time (Figure 2). Reduction in the percentage of remobilization of As over time occurs because As in the soil would be converted from the more labile to more recalcitrant forms with time (Mello et al., 2006).

Based on studies reported in the literature, a period of $24 \mathrm{~h}$ of contact between the mineral adsorbents and the $\mathrm{As}(\mathrm{V})$ solution ensures that the reaction has reached the equilibrium time. Many studies have commented that removal of As increased with the passing of time and the rate is initially quick, after, but subsequently declined as the point of equilibrium was approached (Lenoble et al., 2002; Lafferty and Loeppert, 2005; Jézéquel and $\mathrm{Chu}, 2006$; Yadav et al., 2014). The effect of the contact time between adsorbate and sorbent on the sorption capacity of As indicates that the equilibrium time for As sorption occurred within $3 \mathrm{~h}$ (Yadav et al., 2014). With an increase in contact time of up to $6 \mathrm{~h}$, the authors found no appreciable removal of As. For $\mathrm{Al}$ and $\mathrm{Fe}$ hydroxide, the equilibrium period for $\mathrm{As}(\mathrm{V})$ adsorption reported in the literature is $4 \mathrm{~h}$ after the initial reaction (Lenoble et al., 2002). Another study of As adsorption on Fe oxy-hydroxide yielded an equilibrium time equal to $12 \mathrm{~h}$ (Lafferty and Loeppert, 2005).

Considering the classes of the studied soils, among the Oxisols, the remobilization of As was highest in the P5 profile. This soil showed an As release ratio above $60 \%$, at 60 days of incubation (Figure 2). According to the characterization data of this soil as related to the mineralogy, this sample presents lower gibbsite and high kaolinite contents (> $68 \%$ ), as presented in Table 2 . The presence of gibbsite (Al-OH groups) in the soils favors As adsorption (Manning and Goldberg, 1997; Ladeira et al., 2001; Mello et al., 2006). Consequently, a lower gibbsite content is unfavorable to the adsorption of As. Furthermore, kaolinite is a mineral that presents two surfaces: siloxane (Si-OH group) and gibbsitic (Al-OH group), and the $\mathrm{Si}-\mathrm{OH}$ group is less effective in adsorbing anionic species (Manning and Goldberg, 1997). Because of their negative charged surface, clay minerals, such as kaolinite, generally have a low As adsorption capacity (Zhang et al., 2011).

As regards the Oxisols $\mathrm{P} 1, \mathrm{P} 2$ and $\mathrm{P} 12$, which are clayey and more gibbsitic (Tables 2 and 3), the results of As desorption were consistently low. The behavior of these soils, showed a high As adsorption capacity (Table 4). With the desorption of As, an average reduction of approximately $10 \%$ was observed, pertaining to the three extractive solutions, when comparing the initial and the third run-through of the desorption experiment (Figure 2). The soil P10 presented the highest reduction of As release, comparing the first and third incubation times, with a considerably high percentage of desorption of As, which is probably due to the higher $\mathrm{Fe}$ and $\mathrm{Al}$ oxides of this soil (B horizon) compared to the other soils. Using phosphate as an extractor, for example, this soil showed a reduction of approximately $40 \%$ in As release, decreasing from $84 \%$ in the first time period (1 
day), to $50 \%$ at 60 days contact of the extractive solution with the soil.

The percentage of desorption of As in certain Inceptisols (P20 and P21) was higher than $80 \%$ when using the phosphate as the extractive solution and 72 $\%$ with nitrate. This behavior may be explained by the coarser texture, presence of a 2:1 mineral ratio and especially the lower amount of gibbsite in these soils. This has environmental importance because gibbsite is thermodynamically more stable than Fe oxides and $\mathrm{Al}$ reduction does not occur in the environment. Therefore, a significant amount of As could be sequestered in a gibbsitic phase, (Mello et al., 2006) limiting the mobility of As.

As regards the adsorption of As, we observed that it was not necessarily the soils that obtained the highest MACAs that presented a lower desorption of the element over time. In studies on adsorption, MACAs was correlated mainly with soil texture. On the other hand, comparing the soils $\mathrm{P} 1$ and P5, which present the same proportion of clay $(68 \%)$ and similar adsorption capacity, we observed that the sample P1, with a mineralogy that was more gibbsitic, presented desorption of the element at a considerably lower rate, reaching a difference of 50 $\%$ using phosphate as an extractor. Studies reported in the literature (Lin and Puls, 2000; Zhang et al., 2011; Dias et al., 2019) mention that Al-hydroxides have a high specific surface. Dias et al. (2019) observed that adsorbents with higher values for specific surfaces have the highest adsorption capacity values. This fact is of great importance to the immobilization of As through adsorption and may explain the lower As desorption rate in $\mathrm{P} 1$.

The less weathered soils (P19 to P22), presented up to $70 \%$ desorption of As after one day of contact (Figure 2). Subsequent to this period, As desorption continued to occur at a high rate even after two months of contact between the solution and soil. The Inceptisols (P19 to P22) showed low clay and oxide content, a higher $\mathrm{Fe}_{\mathrm{OX}} / \mathrm{Fe}_{\mathrm{D}}$ ratio and a 2:1 mineral ratio. These attributes contributed to a higher release of As. The low As release in soils and sediments is related to the presence of gibbsite, a large amount of iron oxides and a lack of organic matter in the solid phase (Mello et al., 2006).

Soils and sediments in certain mining regions usually contain significant amounts of As and mining activity may promote an increase in As mobility, culminating in a potential risk of contamination of water sources (Mello et al., 2006). Thus, soils with lower desorption rates of As, such as Oxisols (P1, P2, P3, P6, P7, P11 and P12), are the most commonly recommended for use as geochemical barriers in the immobilization of As. For this purpose, more important than the high MACAs is a low desorption rate of contaminant over time. Soils P3 and P12, for example, have lower MACAs values when compared to the other Oxisols (Table 4), but have lower As desorption rates.

\section{Conclusions}

The mobility of arsenic in the main soil classes in the state of Minas Gerais, Brazil, was attributed to factors such as the state of weathering of the soils, and to factors such as texture, PZSE, gibbsite, oxide contents. The release of As was controlled by the adsorption/desorption equilibrium in the solid phase. A low amount of oxidic clay in the soils, especially gibbsite, favors the release of As.

Oxisols presented the highest maximum adsorption capacity of arsenic (V), followed by Ultisols, Inceptisols and Entisols. The more oxidic the soils, especially gibbsitic, such as Oxisols and certain Ultisols, the greater the adsorption capacity of the As.

The percentage of remobilized As was different across the studied soils, which is due to the soil chemical, physical, and mineralogical characteristics, giving them a specific retention capacity of As. In general, when comparing the soil classes, the release of As was higher in Inceptisols and lower in the more oxidic Oxisols, especially into those that were more gibbisitic. The lower the release of As by soil, the higher the indication to act as a geochemical barrier to immobilize this element.

Among the extractors used to promote the desorption of the As retained in the soil, sodium phosphate showed the highest remobilization power of arsenic, due to the chemical similarity between arsenate and phosphate, followed by the sulfate and nitrate solutions. The presence of these ions in As-contaminated soils implies that in a natural environment it is plausible that they may cause As migration and, consequently, underground and surface water contamination.

Soils with a high MACAs would not necessarily be the most effective when used as a geochemical barrier in the immobilization of As. The soil should also exhibit a low desorption rate of As over time. For the development of a strong As geochemical barrier the soil has to be a clayey Oxisol, with relatively high amounts of $\mathrm{Fe}$ and $\mathrm{Al}$ oxides, especially gibbsite.

\section{Acknowledgments}

The authors are grateful to Brazilian National Council for Scientific and Technological Development $(\mathrm{CNPq})$ and Coordination for the Improvement of Higher Level Personnel (CAPES) for the financial support.

\section{Authors' Contributions}

Conceptualization: Fontes, M.P.F.; Almeida, C.C. Ker, J.C. Data aquisition: Almeida, C.C.; Pereira, T.T.C. Data analysis: Almeida, C.C.; Fontes, M.P.F.; Dias, A. C.; Pereira, T.T.C. Design of methodology: Fontes, M.P.F; Almeida, C.C. Writing and editing: Dias, A.C.; Almeida, C.C.; Fontes, M.P.F. 


\section{References}

Arco-Lázaro, E.; Agudo, I.; Clemente, R.; Bernal, M.P. 2016. Arsenic (V) adsorption-desorption in agricultural and mine soils: effects of organic matter addition and phosphate competition. Environmental Pollution 216: 71-79.

Borba, R.P.; Figueiredo, B.R.; Rawlins, B.; Matschullat, J. 2017. Arsenic in water and sediment in the iron quadrangle, state of Minas Gerais, Brazil. Revista Brasileira de Geociências 30: 558-561.

Catalano, J.G.; Park, C.; Fenter, P.; Zhang, Z. 2008. Simultaneous inner- and outer-sphere arsenate adsorption on corundum and hematite. Geochimica et Cosmochimica Acta 72: 19862004.

Coffin, D. 1963. A method for the determination of free iron in soils and clays. Canadian Journal of Soil Science 43: 7-17.

Cui, Y.; Weng, L. 2013. Arsenate and phosphate adsorption in relation to Oxides composition in soils: LCD modeling. Environmental Science \& Technology 47: 7269-7276.

Dias, A.C.; Fontes, M.P.F.; Reis, C.; Bellato, C.R.; Fendorf, S. 2019. Simplex-Centroid mixture design applied to arsenic (V) removal from waters using synthetic minerals. Journal of Environmental Management 238: 92-101.

Empresa Brasileira de Pesquisa Agropecuária [EMBRAPA]. 2011. Manual of Soil Analysis Methods = Manual de Métodos de Análise de Solos. Embrapa Solos, Rio de Janeiro, RJ, Brazil (in Portuguese).

Empresa Brasileira de Pesquisa Agropecuária [EMBRAPA]. 2013. Brazilian System of Soil Classification = Sistema Brasileiro de Classificação de Solos. Embrapa, Brasília, DF, Brazil (in Portuguese).

Fendorf, S.; Eick, M.J.; Grossl, P.; Sparks, D.L. 1997. Arsenate and chromate retention mechanisms on goethite. 1. Surface structure. Environmental Science \& Technology 31: 315-320.

Fontes, M.P.F.; Almeida, C.C.; Dias, A.C.; Caires, S.M.; Rosa, G.F. 2019. Arsenic in soils: natural concentration and adsorption by oxisols developed from different lithologies. Journal of Agricultural Science 11: 260-268.

Fontes, M.P.F.; Camargo, O.A.; Sposito, G. 2001. Electrochemistry of colloidal particles and its relationship with the mineralogy of highly weathered soils. Scientia Agricola 58: 627-646.

Fontes, M.P.F.; Weed, S.B. 1991. Iron oxides in selected Brazilian Oxisols. I. Mineralogy. Soil Science Society of America Journal 55: 1143-1149.

Goldberg, S.; Johnston, C.T. 2001. Mechanisms of arsenic adsorption on amorphous oxides evaluated using macroscopic measurements, vibrational spectroscopy, and surface complexation modeling. Journal of Colloid and Interface Science 234: 204-216.

Harrison, J.B.; Berkheiser, V.E. 1982. Anion interactions with freshly prepared hydrous iron oxides. Clays and Clay Minerals 30: 97-102.

Hartley, W.; Lepp, N.W. 2008. Remediation of arsenic contaminated soils by iron-oxide application, evaluated in terms of plant productivity, arsenic and phytotoxic metal uptake. Science of The Total Environment 390: 35-44.

Jackson, M.L. 1979. Soil Chemical Analysis: Advanced Course. 2ed. University of Wisconsin, Madison, WI, USA.
Jézéquel, H.; Chu, K.H. 2006. Removal of arsenate from aqueous solution by adsorption onto titanium dioxide nanoparticles. Journal of Environmental Science and Health. Part A 41: 1519-1528.

Katsoyiannis, I.A.; Zouboulis, A.I. 2002. Removal of arsenic from contaminated water sources by sorption onto ironoxide-coated polymeric materials. Water Research 36: 51415155.

Khaska, M.; Le Gal La Salle, C.; Sassine, L.; Cary, L.; Bruguier, O.; Verdoux, P. 2018. Arsenic and metallic trace elements cycling in the surface water-groundwater-soil continuum down-gradient from a reclaimed mine area: isotopic imprints. Journal of Hydrology 558: 341-355.

Komárek, M.; Vaněk, A.; Ettler, V. 2013. Chemical stabilization of metals and arsenic in contaminated soils using oxides: a review. Environmental Pollution 172: 9-22.

Ladeira, A.C.; Ciminelli, V.S. 2004. Adsorption and desorption of arsenic on an oxisol and its constituents. Water Research 38: 2087-2094.

Ladeira, A.C.Q.; Ciminelli, V.S.T.; Duarte, H.A.; Alves, M.C.M.; Ramos, A.Y. 2001. Mechanism of anion retention from EXAFS and density functional calculations: arsenic (V) adsorbed on gibbsite. Geochimica et Cosmochimica Acta 65: 1211-1217.

Lafferty, B.J.; Loeppert, R.H. 2005. Methyl arsenic adsorption and desorption behavior on iron oxides. Environmental Science \& Technology 39: 2120-2127.

Lenoble, V.; Bouras, O.; Deluchat, V.; Serpaud, B.; Bollinger, J.-C. 2002. Arsenic adsorption onto pillared clays and iron oxides. Journal of Colloid and Interface Science 255: 52-58.

Lin, Z.; Puls, R.W. 2000. Adsorption, desorption and oxidation of arsenic affected by clay minerals and aging process. Environmental Geology 39: 753-759.

Lytle, D.A.; Sorg, T.J.; Snoeyink, V.L. 2005. Optimizing arsenic removal during iron removal: theoretical and practical considerations. Journal of Water Supply: Research and Technology - Aqua 54: 545-560.

Maji, S.K.; Pal, A.; Pal, T. 2008. Arsenic removal from reallife groundwater by adsorption on laterite soil. Journal of Hazardous Materials 151: 811-820.

Mamindy-Pajany, Y.; Hurel, C.; Marmier, N.; Roméo, M. 2009. Arsenic adsorption onto hematite and goethite. Comptes Rendus Chimie 12: 876-881.

Manning, B.A.; Goldberg, S. 1997. Adsorption and stability of arsenic (III) at the clay mineral-water interface. Environmental Science \& Technology 31: 171-177.

McKeague, J.; Day, J. 1966. Dithionite-and oxalate-extractable $\mathrm{Fe}$ and $\mathrm{Al}$ as aids in differentiating various classes of soils. Canadian Journal of Soil Science 46: 13-22.

Mello, J.; Roy, W.; Talbott, J.; Stucki, J. 2006. Mineralogy and arsenic mobility in arsenic-rich Brazilian soils and sediments. Journal of Soils and Sediments 6: 9-19.

Ona-Nguema, G.; Morin, G.; Juillot, F.; Calas, G.; Brown, G.E. 2005. EXAFS analysis of arsenite adsorption onto two-line ferrihydrite, hematite, goethite, and lepidocrocite. Environmental Science \& Technology 39: 9147-9155.

Parks, G.A.; Bruyn, P.L. 1962. The zero point of charge of oxides. The Journal of Physical Chemistry 66: 967-973. 
Pimentel, H.; Lena, J.; Nalini, H. 2003. Studies of water quality in the Ouro Preto region, Minas Gerais, Brazil: the release of arsenic to the hydrological system. Environmental Geology 43: 725-730.

Schwertmann, U. 1973. Use of oxalate for Fe extraction from soils. Canadian Journal of Soil Science 53: 244-246.

Skorupa, A.L.A.; Guilherme, L.R.G.; Curi, N.; Silva, C.P.C.; Scolforo, J.R.S.; Marques, J.J.G.S. 2012. Soil properties under native vegetation in Minas Gerais, Brazil: distribution by phytophysiognomy, hydrography and spatial variability. Revista Brasileira de Ciência do Solo 36: 11-22 (in Portuguese, with abstract in English).

Smedley, P.; Kinniburgh, D. 2002. A review of the source, behaviour and distribution of arsenic in natural waters. Applied Geochemistry 17: 517-568.

Soil Survey Staff. 2014. Keys to Soil Taxonomy. USDA-Natural Resources Conservation Service, Washington, DC, USA.

United States Environmental Protection Agency [USEPA]. 2007. Method 3051A: Microwave Assisted Acid Digestion of Sediments, Sludges, Soils, and Oils. USEPA, Washington, DC, USA.

Van Raij, B.; Peech, M. 1972. Electrochemical properties of some oxisols and alfisols of the tropics. Soil Science Society of America Journal 36: 587-593.
Varejão, E.V.; Bellato, C.R.; Fontes, M.P.; Mello, J.W. 2011. Arsenic and trace metals in river water and sediments from the southeast portion of the Iron Quadrangle, Brazil. Environmental Monitoring and Assessment 172: 631-642.

World Health Organization [WHO]. 1993. Water Sanitation \& Health. Guidelines for Drinking Water Quality. WHO, Geneva, Switzerland.

World Health Organization [WHO]. 2001. Environmental Levels and Human Exposure. WHO, Geneva, Switzerland.

Yadav, L.S.; Mishra, B.K.; Kumar, A.; Paul, K.K. 2014. Arsenic removal using bagasse fly ash-iron coated and sponge iron char. Journal of Environmental Chemical Engineering 2: 1467-1473.

Yeomans, J.C.; Bremner, J.M. 1988. A rapid and precise method for routine determination of organic carbon in soil. Communications in Soil Science and Plant Analysis 19: 14671476.

Zhang, H.; Selim, H. 2005. Kinetics of arsenate adsorptiondesorption in soils. Environmental Science \& Technology 39: 6101-6108.

Zhang, X.; Lin, S.; Chen, Z.; Megharaj, M.; Naidu, R. 2011. Kaolinite-supported nanoscale zero-valent iron for removal of $\mathrm{Pb}^{2+}$ from aqueous solution: reactivity, characterization and mechanism. Water Research 45: 3481-3488. 